\title{
Molecular Characteristics of Uveal Melanoma: Insights from the Cancer Genome Atlas (TCGA) Project
}

\author{
Mathieu F. Bakhoum ${ }^{1}$ and Bita Esmaeli ${ }^{2, *}$ \\ 1 Shiley Eye Institute, Jacobs Retina Center, Viterbi Family Department of Ophthalmology, \\ University of California San Diego, La Jolla, CA 92093, USA \\ 2 Orbital Oncology and Ophthalmic Plastic Surgery, Department of Plastic Surgery, \\ The University of Texas MD Anderson Cancer Center, Houston, TX 77030, USA \\ * Correspondence: besmaeli@mdanderson.org; Tel.: +1-713-792-4457; Fax: +1-713-794-4662
}

Received: 6 July 2019; Accepted: 22 July 2019; Published: 27 July 2019

check for updates

\begin{abstract}
The Cancer Genome Atlas (TCGA) uveal melanoma project was a comprehensive multi-platform deep molecular investigation of 80 uveal melanoma primary tissue samples supported by the National Cancer Institute. In addition to identification of important mutations for the first time, it identified four different clusters (subgroups) of patients paralleling prognosis. The findings of the TCGA marker paper are summarized in this review manuscript and other investigations that have stemmed from the findings of the TCGA project are reviewed.
\end{abstract}

Keywords: uveal melanoma; TCGA; whole exome sequencing; RNA seq; methylation; immune infiltrates

\section{Background and Historical Perspective}

Uveal melanoma (UM), the most common primary intraocular tumor in adults, is characterized by marked variability in its ability to metastasize. Up to half the patients with UM develop distant metastases, most commonly to the liver [1-3]. Once metastasis is clinically detected, the median survival is less than 12 months [2,4]. The Collaborative Ocular Melanoma Study (COMS), a large multi-center prospective trial, showed that local radiotherapy or enucleation are equally effective in achieving local control of the primary tumor with no difference in incidence of metastatic disease. Despite achieving local control of the primary tumor, overall survival rates have remained constant over the last four decades [5]. It is thought that micro-metastases may have already occurred by the time of enucleation, and that the chance of developing clinically significant metastases largely depends on the genetic underpinnings of the primary tumor. This variable metastatic proclivity was first demonstrated by Callender, who noted that UM with a predominant epithelioid cellular morphology, characterized by large nuclei, have worse prognosis than those with a predominantly spindle morphology [6,7]. Recurrent cytogenetic abnormalities have also been noted in UM and were found to correlate with metastatic tendencies. For instance, loss of chromosome 3 (monosomy 3 ) and gain of chromosome 8q are strong predictors of metastasis, whereas gain of $6 \mathrm{p}$ confers a better prognosis [8-13]. These non-random karyotypic aberrancies indicated that tumors with worse prognosis may have a unique molecular profile. In fact, UM with monosomy 3 were found to have a distinct gene expression profile [14]. This led to the development of a clinical prognostic test which has the ability to stratify tumors, solely based on gene expression patterns, into two major classes, with strikingly different survival outcomes $[15,16]$.

The Cancer Genome Atlas (TCGA) project was a multi-center institutional effort, supported by the National Institute of Health, with the aim of providing a comprehensive genetic analysis of different cancers and establishing correlations with clinical outcomes. Eighty primary UM, with their associated 
clinicopathologic data, were included in a Rare Tumor Project of TCGA [17]. Mutations, genomic copy number alterations, transcriptomic and methylation profiles were analyzed for all eighty specimens. Additionally, whole genome sequencing was performed on fifty specimens and reverse-phase protein array (RPPA) was performed on eleven specimens. This review focuses on the main findings and analysis generated from TCGA, which was reported by Robertson et al. [17].

\section{Mutational Landscape}

Unlike cutaneous melanoma, the mutational burden in UM is low. The median somatic mutation density in the TCGA cohort was found to be 1.1 per $\mathrm{Mb}$ in $\mathrm{UM}$ versus 18 per $\mathrm{Mb}$ in cutaneous melanoma $[17,18]$. There was no evidence of UV radiation mutational signature in UM consistent with prior observations [19]. Nine genes were significantly mutated in the cohort-GNAQ, GNA11, BAP1, SF3B1, EIF1AX, CYSLTR2, SRSF2, MAPKAPK5, and PLCB4 [17], as shown in Table 1. Mutations in alpha G-protein subunits, GNAQ and GNA11, were found in $92.5 \%$ of the samples, in a mutually exclusive pattern consistent with prior observations [17,20-22]. Tumors that did not harbor these mutations were found to have mutations in CYSLTR2, a G-protein-coupled receptor, in 4\% of samples and in PLCB4, a downstream effector of GNAQ signaling in $2.5 \%$ of samples $[17,19,23]$, highlighting the involvement of G-protein signaling in the biology of uveal melanoma. There was no difference in outcomes (overall survival or metastasis) between these mutations. This suggests that activating mutations in GNAQ/11 are an early event in UM oncogenesis. In fact, mutations in GNAQ/11 were found in most benign nevi $[20,24,25]$. In vitro studies have supported the potential role of activating GNAQ/11 mutations in cellular growth. GNAQ/11.Q209L mutation was shown to activate Yes-associated protein (YAP) and transcriptional coactivator with PDZ-binding motif (TAZ), two transcriptional enhancers with oncogenic potential [26-28]. Ectopic expression of the activating mutation GNAQ/11.Q209L in zebrafish along with inactivation of the tumor suppressor TP53 led to tumor formation [29,30], while expression of GNAQ/11.Q209L alone led to profound pigmentation defects without oncogenic transformation, supporting the hypothesis that the activating GNAQ/11 mutations are precursor events requiring a 'second hit' in order to lead to malignant transformation, as shown in Figure 1 [31].

Tumor-initiating mutations
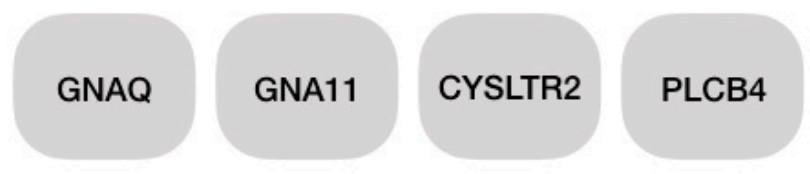

\section{Prognostic mutations}

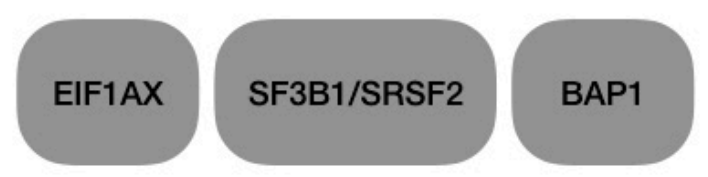

Figure 1. Two layers of mutations in uveal melanoma (UM). Mutations in genes involved in G-protein signaling are present in $98 \%$ of samples in a nearly mutually exclusive manner. They are also present in benign choroidal nevi and are therefore thought to occur in the earlier stages of tumor formation. A second layer of mutations occurs in EIF1AX, SF3B1, SRSF2, and BAP1. They are found in $66 \%$ of samples in a nearly mutually exclusive manner as well. These mutations confer different prognoses.

A second layer of mutations consist of mutations in SF3B1, EIF1AX, BAP1, and were found in a nearly mutually exclusive manner. In contrast to mutations in genes involved in G-protein signaling, these mutations were associated with markedly distinct prognoses. Samples with BAP1 mutations (33\% of the cohort) had unique somatic copy number alterations (SCNA) and gene expression profiles and were associated with poor survival outcomes. All tumors with BAP1 mutations had genomic copy loss in chromosome 3, while none of those with EIF1AX and only 22\% of UM with SF3B1 mutations had monosomy 3. Somatic mutations in $B A P 1$, located on 3p21.1, were previously 
shown to confer a strong predilection for metastasis [17,32,33]. In the TCGA cohort, single nucleotide polymorphism/insertion-deletion (SNP/indel) analysis of monosomy 3 whole exome sequencing (WES) initially identified BAP1 mutation in $40.5 \%$ of monosomy 3 samples. RNA/DNA assembly-based methods led to the identification of additional BAP1 alterations, raising the percentage to 83.3\% in UM with monosomy 3 , in line with other reports [17,32]. It is possible that deeper whole genome sequencing with longer reads, which was not performed, could have detected additional BAP1 alterations in UM with monosomy 3. EIF1AX and SF3B1 mutations were present in 35\% of samples.

Despite the strong association with worse outcomes, a mechanistic link between BAP1 loss and highly aggressive UM remains elusive. BAP1, which was initially identified in a yeast 2-hybrid screen as a protein that interacts with BRCA1 [34], is a deubiquitinating enzyme. BAP1-mediated deubiquitination of $\gamma$-tubulin and MCRS1 (microspherule protein 1) has been shown to contribute to chromosomal stability [35,36]. BAP1 has also been implicated in DNA double-strand break repair [37,38]. Interestingly, in the TCGA report, genes involved in DNA damage repair/response (DDR) were upregulated in monosomy 3 tumors harboring BAP1 mutations compared to disomy 3 tumors with SF3B1 mutations [17].

Table 1. Genes frequently mutated in uveal melanoma. Source: cBioPortal $[39,40]$.

\begin{tabular}{|c|c|c|}
\hline Gene & $\begin{array}{l}\text { Percentage of Samples } \\
\text { with Mutations }\end{array}$ & $\begin{array}{c}\text { Recurrent Alleles-Protein } \\
\text { Change (Frequency) }\end{array}$ \\
\hline GNAQ & $50 \%$ & $\begin{array}{c}\text { Q209P/L (90\%) } \\
\text { R183Q (5\%) } \\
\text { G48*/V (5\%) }\end{array}$ \\
\hline GNA11 & $45 \%$ & $\begin{array}{l}\text { Q209L (94\%) } \\
\text { R183C (3\%) } \\
\text { R166H (3\%) }\end{array}$ \\
\hline BAP1 & $33 \%$ & Multiple* \\
\hline SF3B1 & $23 \%$ & $\begin{array}{c}\mathrm{R} 625 \mathrm{H} / \mathrm{C}(78 \%) \\
\mathrm{K} 666 \mathrm{~T}(11 \%) \\
\mathrm{H} 662 \mathrm{R}(5 \%) \\
\mathrm{T} 663 \mathrm{P}(5 \%)\end{array}$ \\
\hline EIF1AX & $13 \%$ & $\begin{array}{c}\text { G6D }(20 \%) \\
\text { G8R }(20 \%) \\
\text { G9R/D }(20 \%) \\
\text { G15D }(20 \%) \\
\text { W70R }(10 \%)\end{array}$ \\
\hline CYSLTR2 & $4 \%$ & L129Q (100\%) \\
\hline SRSF2 & $4 \%$ & Multiple \\
\hline PLCB4 & $2.5 \%$ & D630N/V/Y (100\%) \\
\hline МАРКАРК5 & $2.5 \%$ & Truncating mutations \\
\hline
\end{tabular}

Mutations in SRSF2 were found in three samples which had wildtype EIF1AX and SF3B1. Samples with SRSF2 mutations had an SCNA profile similar to that of SF3B1, suggesting a common molecular basis for both genes in the UM development. SRSF2 gene product is a member of the serine/arginine-rich family of pre-mRNA splicing factors, and SF3B1 encodes subunit 1 of the splicing factor $3 b$ protein complex. In fact, UM with mutations in either of those genes had alternatively spliced transcripts in a subset of genes compared to UM with wildtype SF3B1/SRSF2.

\section{Patterned Aneuploidy}

Aneuploidy denotes a genomic state where there is an aberrant number of chromosomes, i.e., a non-euploid state. Aneuploidy is very prevalent in cancer and is thought to arise from chromosomal 
missegregation during mitosis [41-45]. Consequently, genomic heterogeneity can facilitate tumor evolution $[44,46]$. In the TCGA-UM cohort, chromosomal alterations were inferred from whole exome sequencing and SNP microarrays. Unsupervised clustering of all eighty samples showed that they segregate in four distinct clusters with different prognosis. Clusters 1 and 2 retained both copies of chromosome 3 while clusters 3 and 4 were mainly characterized by monosomy 3 . Clusters 1 and 2, which had better prognoses, were enriched for $6 \mathrm{p}$ gain. Expectedly, BAP1 mutations were limited to clusters 3 and 4 , which were defined by monosomy 3. EIF1AX mutations were only present in cluster 1 , and mutations in SF3B1/SRSF2 were mainly present in cluster 2 and, to a lesser extent, in cluster 3. Gain of $8 \mathrm{q}$ was present in clusters 2,3 , and 4 , with the latter cluster having high copy gain or amplification of $8 \mathrm{q}$. Essentially, while 8q gain was seen in a subset of UM with disomy 3, nearly all samples with monosomy 3 had gain or amplification of 8 q. Moreover, isodisomy 8 was seen in a subset of UM with monosomy 3 -these had the worst prognosis. These recurrent chromosomal alterations were in agreement with prior observations [9-12,47-52]. Other karyotypic abnormalities appeared more random but were more abundant in cluster 4 (monosomy 3/BAP1-aberrant/8q amplification) while virtually absent in cluster 1 (disomy 3/BAP1-competent). Whole genome doubling was also noted in tumors with monosomy 3 . These associations hint to a possible role for BAP1 loss in inducing chromosomal instability. However, it must be cautioned that chromosomal instability and aneuploidy are not synonymous. The former is a dynamic state caused by ongoing errors in chromosome segregation, while the latter is a characterization of a static state, which in many cases may result from ongoing chromosomal instability [41]. Selective genomic copy numbers may also occur independent of chromosomal missegregation. For instance, extrachromosomal DNA segments may lead to amplification of genomic regions containing oncogenes [53]. Thus, it should be pointed out that recurrent chromosomal abnormalities in UM do not necessarily indicate higher levels of chromosomal instability. For instance, UM with 6p gain is aneuploid by definition, but may have a lower level of chromosomal instability than UM with monosomy 3 and 8q gain.

Given that BAP1 mutations were always present in the context of monosomy 3, Robertson et al. analyzed cancer cell fractions to estimate the relative timing of BAP1 loss versus monosomy 3 in the TCGA uveal melanoma cohort [17]. Cancer cell fractions of monosomy 3 were close to 1 (mean 0.97), whereas those of BAP1 alterations were lower (mean 0.88), and other passenger mutations on chromosome 3 occurred with much less frequency (mean 0.60). This suggests that loss of chromosome 3 occurs prior to $B A P 1$ alterations which occurs at a higher frequency than other passenger mutations located on chromosome 3 .

\section{Epigenetic Fingerprints}

Another means by which cancer cells may up- or downregulate gene expression is through DNA methylation. $\mathrm{CpG}$ islands are CG-rich regions where a cytosine nucleotide can be methylated by DNA methyltransferases to form 5-methylcytosine. Promoter methylation often leads to gene silencing. In cancer, hyper/hypo-methylation is common, and is a means by which a cell can silence or upregulate genes [54]. TCGA provided, for the first time, a comprehensive analysis of DNA methylation profiles of UM using the Infinium HumanMethylation450 BeadChip Kit (Illumina), a microarray-based test which surveys 450,000 methylation loci. Clustering of the most variable 1\% of these probes (approximately 4500 probes) revealed that monosomy 3/BAP1-aberrant tumors had a unique methylation profile. Within disomy 3 UM, tumors with EIF1AX mutations had a different methylation profile than those with SF3B1 mutations. This clustering was similar to that of SCNA, suggesting an epigenetic role in the evolution of UM.

\section{Transcriptomic Analysis}

Unbiased clustering of mRNA transcripts revealed four clusters. Expectedly, monosomy 3/BAP1-aberrant tumors had a distinct transcriptomic profiles than tumors with disomy 3 and high BAP1 levels. These two main clusters also correlated with the prognostic twelve-set marker genes that are commonly used in clinical prognostication [15]. Each cluster could be further subdivided into 
two groups. Unbiased clustering of long noncoding (lncRNA) followed the same patterns as mRNA. LncRNAs CYTOR, PVT1, and BANCR, which are associated with other solid cancers [55,56], were more abundant in the poor-prognosis clusters 3 and 4. PVT1, which has been shown to be associated with MYC protein stabilization [57]. Clusters based on microRNA (miRNA) were slightly different than mRNA or lncRNA subtypes.

Differential gene expression analysis revealed that the poor-prognosis mRNA cluster 4 was enriched for immune genes and genes located on 8q. Unlike many other malignancies, including cutaneous melanoma, the presence of an immune infiltrate and increased expression of human leukocyte antigens (HLA) in UM has been associated with poor prognosis [58,59]. For instance, immunohistochemical analysis showed that tumors with high lymphocytes (containing more than 100 lymphocytes per 20 high power field (HPF)) correlated with a 15 year survival rate of $37 \%$, as opposed to $70 \%$ when the tumors had less than 100 lymphocytes per $20 \mathrm{HPF}$ [60]. Similarly, tumors with higher immune infiltration were associated with worse prognostic factors, such as monosomy 3 , and patients had higher rates of metastasis [58-63]. In the TCGA cohort, the frequency of an immune infiltrate was inferred by DNA methylation and RNA-seq, and was estimated to constitute $30 \%$ of monosomy 3 UM while absent in disomy 3 UM. Transcriptomic analysis showed enrichment of HLA genes and others involved in interferon- $\gamma$ signaling, $T$ cell invasion, cytotoxicity, and immunosuppression in high-risk tumors. This finding correlated with a prior analysis that was based on whole genome sequencing of UM [52]. Dissecting this unique immune infiltrate is significant because metastatic UM do not respond to immune checkpoint inhibitors (see below).

\section{Pathway Discovery}

Clustering of UM based on their SCNA, methylation, mRNA, miRNA, or lncRNA profiles led to four major clusters in each instance, as shown in Figure 2. Monosomy 3 UM had distinct genomic, transcriptomic, and epigenetic profiles than disomy $3 \mathrm{UM}$. Both disomy 3 and monosomy 3 UM could be further subdivided into two subgroups based on their SCNA profiles, with a more refined prognosis. Transcriptomic clustering allowed subdividing disomy 3 and monosomy 3 UM into two distinct groups as well, albeit this clustering was not fully concordant with SCNA clustering. Nevertheless, subgrouping into distinct clusters with different outcomes insinuate a biological basis behind different metastatic tendencies within high-risk tumors. In order to elucidate possible pathways associated with metastasis, Robertson et al. applied PARADIGM to infer subset-specific pathways from multi-dimensional genomics data. This led to the identification of four major and one minor groups [17]. Clusters 3 and 4 were BAP1-aberrant/monosomy 3 tumors. Cluster 4 was enriched for genes involved in DNA damage repair/response (DDR) and hypoxia. MYC signaling was also highest in cluster 4. MYC is an oncogenic transcription factor expressed on the long arm of chromosome 8, which is also amplified in cluster 4 . It can complex with MAX and/or MIZ1. Robertson et al. found that targets of MYC/MAX/MIZ were represented in cluster 4. Interestingly, MYC/MAX complex activity levels were high in tumors with no $8 \mathrm{q}$ gain indicating that other factors, in addition to $8 \mathrm{q}$ gain, may enhance MYC signaling. Additional genes upregulated in the high-risk cluster 4 included JUN-FOS and JAK2-STAT1/3, both of which are implicated in multiple malignancies. JAK-STAT signaling can alter transcription driven by extracellular ligand binding, including cytokines [64,65]. Consistently, cluster 4 tumors were enriched for immune-related genes. Cluster 3 tumors on the other hand were enriched in genes involved in cell cycling and cellular proliferation, with low enrichment in genes involved in DDR and hypoxia, when compared to cluster 4 . Even though both clusters had monosomy 3 and low BAP1 levels, they had different signaling profiles. Elucidating biological pathways associated with worse outcomes (cluster 4 versus 3) can provide insight into biological pathways that drive tumor evolution. 


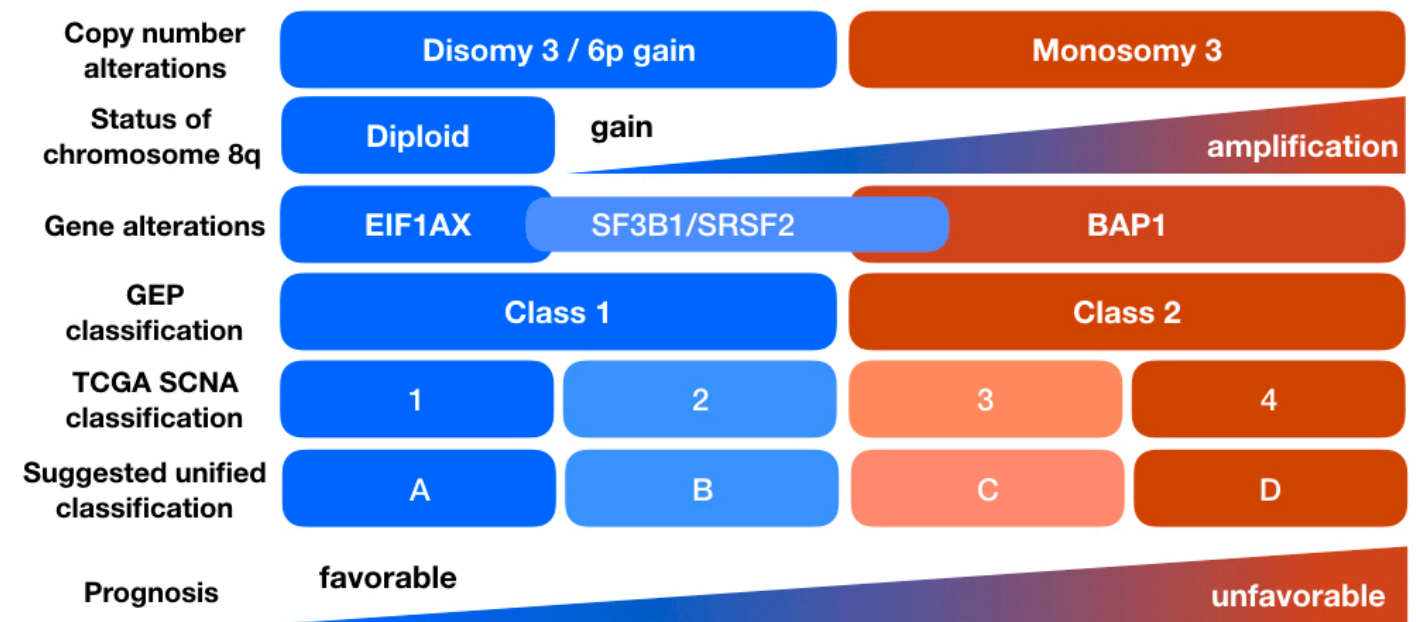

Figure 2. An overview of UM subtypes. Prognostic classes can be inferred from either somatic copy number alterations (SCNA), gene alterations, or gene expression. The A, B, C, and D classification was suggested to avoid confusion between the numerical classification used in both the Cancer Genome Atlas (TCGA) and the commercially available test (GEP classification).

\section{Clinical Prognostic Tests}

Clinical prognostication is important for many reasons. Foremost, patients often want to know their prognosis. Second, tumor prognostic classification can modify the frequency of metastatic surveillance in the various prognostic groups. Third, tumor stratification can help identify high-risk patients that may be appropriate for enrollment in clinical trials for adjuvant therapy. TCGA was the largest comprehensive study that concurrently evaluated multiple prognostic parameters and associated them with clinical outcomes. In order to avoid confusion between TCGA and the commercial Castle Biosciences classification (Class 1A, 1B, or 2), Jager et al. in a review manuscript based on TCGA findings suggested labelling TCGA-clusters using an alphabetical nomenclature- $-\mathrm{A}, \mathrm{B}, \mathrm{C}$, and D for clusters 1, 2, 3, and 4, respectively [66]. Vichitvejpaisal et al. applied a simplified TCGA classification on $658 \mathrm{UM}$ samples from fine needle aspiration and validated TCGA findings in a large retrospective cohort [67]. Class A was defined as disomy 3 tumors, class B as disomy 3 tumors with 8q gain, class $C$ as monosomy 3 tumors with $8 \mathrm{q}$ gain, and class D tumors as monosomy 3 tumors with $8 \mathrm{q}$ amplification. It must be cautioned however that the TCGA classification hinges on the platform analyzed (RNA vs. DNA). As we mentioned, clusters 1 and 2 can be distinguished from clusters 3 and 4 using any platforms. However, assigning a disomy 3 UM sample to cluster 1 versus 2, or a monosomy 3 UM sample to cluster 3 versus 4 , may differ depending on the platform used. We suggest that when referring to TCGA classification, the platform should be clearly indicated.

In the United States, ocular oncologists utilize either a DNA-based test which relies on karyotypic analysis of the tumor (mainly monosomy $3,8 \mathrm{q}$, and $6 \mathrm{p}$ gain) or a RNA-based test, commercially offered by Castle Biosciences, wherein a 12-gene panel is used to estimate prognosis (Class 1A, 1B, or 2, with low, intermediate, and high risk of metastasis, respectively). In Europe, chromosomal analysis is more prevalent. The multi-dimensional TCGA-UM analysis indicated that segregating tumors into two major prognostic groups can be equally achieved by analyzing chromosome 3 status (disomy 3 vs. monosomy 3) or analyzing the transcriptome (Castle Biosciences GEP class 1 vs. 2/TCGA clusters 1 and 2 vs. 3 and 4). In other words, clusters 3 and 4 (Castle Biosciences GEP class 2) reflect the transcriptome of monosomy 3 tumors. While both approaches (RNA or DNA-based) may identify identical tumors, different tests may have different sensitivities, specificities, and limitations. For instance, chromosome 3 status can be inferred from whole genome sequencing (WGS), WES, SNP, multiplex ligation-dependent probe amplification (MLPA), or fluorescence in situ hybridization (FISH). Gene expression profiles rely on comparing relative levels of RNA from a 12-gene panel. This test's major drawback is its inability to distinguish melanoma cells from other choroidal tumors [68]. It is 
likely that test-specific limitations may account for reported discrepancies in survival data reported in various studies, rather than superiority of one approach over another. These inherent variations must be taken into consideration when reporting survival or metastasis outcomes, or enrolling patients in prospective trials for adjuvant therapy. It is also important to note that even though transcriptomic clustering segregated disomy 3 tumors into two subgroups, there was no evidence that these groups correlated with Castle class 1 subgroups (1A versus 1B). In addition, the TCGA SCNA analysis allowed for the first time the identification of two different groups with different outcomes in tumors with monosomy 3-a distinction that was not identified through prior prognostication methods, as shown in Figure 2.

\section{Therapeutic Implications}

$\mathrm{UM}$ can be treated by iodine or ruthenium plaque radiotherapy, proton beam radiation therapy, or enucleation. These interventions, albeit successful in controlling the primary tumor and reducing recurrence, do not reduce the chance of metastasis. Ideally, targeted therapies would be effective against the primary tumor as well as micrometastases. Activating mutations in GNAQ/11 are prevalent in UM, and are also found in choroidal nevi $[20,24,25]$. In the TCGA cohort, mutations in GNAQ/11, CYSLTR2, and PLCB4 (2.5\%) were found in $92.5 \%, 4 \%$, and $2.5 \%$ of the samples, respectively, highlighting the involvement of G-protein signaling in the biology of uveal melanoma. In essence, inhibiting GNAQ/11 or their downstream signaling appears as a promising approach. However, targeting GNAQ/11 downstream effectors have not led to successful outcomes in metastatic UM [69,70]. Direct inhibition of oncoproteins $\mathrm{G} \alpha \mathrm{q} / 11$ may be a better alternative. This can be achieved by a selective pharmacologic inhibitor FR900359 (FR), which has shown efficacy in pre-clinical models [71-76]. Interestingly, even though GNAQ/11 mutations were present in $93 \%$ of the samples, protein analysis showed that levels of PKC, a downstream effector of GNAQ/11, were markedly higher in monosomy 3/BAP1-aberrant UM, indicating that GNAQ/11 signaling may be further enhanced in M3 tumors [17].

Immune checkpoint inhibitors have proven very beneficial in the management of metastatic cutaneous melanoma and in a few cases of metastatic conjunctival melanoma [77]. Yet, attempts to apply this approach in metastatic uveal melanoma have failed [70]. It is possible that the relatively low mutational burden, and consequently the paucity of neoantigens, may partly explain why metastatic UM do not respond to immune checkpoint inhibitors. However, it must be cautioned that the inverse relationship between tumor mutational burden and response to immunotherapy is variable across different tumor types [78]. Thus, there are likely other underlying factors in addition to a lower mutational burden that may explain UM's resistance to immune checkpoint inhibitors. For instance, UM cells may secrete inhibitory ligands to dampen anti-tumor immunity. Transcript levels of IDO1 and TIGIT, both of which are immune checkpoint inhibitors that can limit T cells' cytotoxic effects, were high in monosomy $3 \mathrm{UM}$ with high CD8 levels. Robertson et al. postulate that combinations of agents targeting IDO1 and TIGIT along with CTLA-4 or PD1 inhibition may therefore prove beneficial [17].

\section{Conclusions}

In summary, the comprehensive multi-dimensional analysis by TCGA revealed that UM can be subdivided into four distinct groups with different outcomes rather than three prognostic groups previously reported using the commercially available RNA-based prognostic tests. TCGA findings allowed us to validate many prognostic markers currently used in clinical practice in a single cohort of patients using a comprehensive integrated approach. The data from the integrative pathway analysis in TCGA UM report are publicly available to investigators and this great resource provides a biological platform for developing effective targeted therapies for UM patients in the future.

Author Contributions: Both authors participated in the preparation of the manuscript.

Funding: The senior author (BE) received funding from TCGA to conduct the original study.

Conflicts of Interest: The authors declare no conflict of interest. 


\section{References}

1. Kujala, E.; Mäkitie, T.; Kivelä, T. Very long-term prognosis of patients with malignant uveal melanoma. Invest. Ophthalmol. Vis. Sci. 2003, 44, 4651-4659. [CrossRef] [PubMed]

2. Diener-West, M.; Reynolds, S.M.; Agugliaro, D.J.; Caldwell, R.; Cumming, K.; Earle, J.D.; Hawkins, B.S.; Hayman, J.A.; Jaiyesimi, I.; Jampol, L.M.; et al. Collaborative ocular melanoma study group development of metastatic disease after enrollment in the COMS trials for treatment of choroidal melanoma: Collaborative ocular melanoma study group report No. 26. Arch. Ophthalmol. 2005, 123, 1639-1643. [PubMed]

3. Andreoli, M.T.; Mieler, W.F.; Leiderman, Y.I. Epidemiological trends in uveal melanoma. Br. J. Ophthalmol. 2015, 99, 1550-1553. [CrossRef] [PubMed]

4. Collaborative Ocular Melanoma Study Group. The COMS randomized trial of iodine 125 brachytherapy for choroidal melanoma: V. Twelve-year mortality rates and prognostic factors: COMS report No. 28. Arch. Ophthalmol. 2006, 124, 1684-1693. [CrossRef] [PubMed]

5. Singh, A.D.; Turell, M.E.; Topham, A.K. Uveal melanoma: Trends in incidence, treatment, and survival. Ophthalmology 2011, 118, 1881-1885. [CrossRef] [PubMed]

6. Callender, G.R. Malignant melanotic tumors of the eye: A study of histologic types in 111 cases. Trans. Am. Acad. Ophthalmol. Otolaryngol. 1931, 36, 131-142.

7. McLean, I.W.; Foster, W.D.; Zimmerman, L.E.; Gamel, J.W. Modifications of Callender's classification of uveal melanoma at the Armed Forces Institute of Pathology. Am. J. Ophthalmol. 1983, 96, 502-509. [CrossRef]

8. Bonaldi, L.; Midena, E.; Filippi, B.; Tebaldi, E.; Marcato, R.; Parrozzani, R.; Amadori, A. FISH analysis of chromosomes 3 and 6 on fine needle aspiration biopsy samples identifies distinct subgroups of uveal melanomas. J. Cancer Res. Clin. Oncol. 2008, 134, 1123-1127. [CrossRef] [PubMed]

9. Prescher, G.; Bornfeld, N.; Hirche, H.; Horsthemke, B.; Jöckel, K.H.; Becher, R. Prognostic implications of monosomy 3 in uveal melanoma. Lancet 1996, 347, 1222-1225.

10. Van den Bosch, T.; van Beek, J.G.M.; Vaarwater, J.; Verdijk, R.M.; Naus, N.C.; Paridaens, D.; de Klein, A.; Kiliç, E. Higher percentage of FISH-determined monosomy 3 and $8 \mathrm{q}$ amplification in uveal melanoma cells relate to poor patient prognosis. Investig. Opthalmol. Vis. Sci. 2012, 53, 2668-2674. [CrossRef]

11. Damato, B.; Dopierala, J.A.; Coupland, S.E. Genotypic profiling of 452 choroidal melanomas with multiplex ligation-dependent probe amplification. Clin. Cancer Res. 2010, 16, 6083-6092. [CrossRef] [PubMed]

12. Sisley, K.; Rennie, I.G.; Parsons, M.A.; Jacques, R.; Hammond, D.W.; Bell, S.M.; Potter, A.M.; Rees, R.C. Abnormalities of chromosomes 3 and 8 in posterior uveal melanoma correlate with prognosis. Genes Chromosomes Cancer 1997, 19, 22-28. [CrossRef]

13. Prescher, G.; Bornfeld, N.; Becher, R. Nonrandom chromosomal abnormalities in primary uveal melanoma. J. Natl. Cancer Inst. 1990, 82, 1765-1769. [CrossRef] [PubMed]

14. Tschentscher, F.; Hüsing, J.; Hölter, T.; Kruse, E.; Dresen, I.G.; Jöckel, K.-H.; Anastassiou, G.; Schilling, H.; Bornfeld, N.; Horsthemke, B.; et al. Tumor classification based on gene expression profiling shows that uveal melanomas with and without monosomy 3 represent two distinct entities. Cancer Res. 2003, 63, 2578-2584. [PubMed]

15. Onken, M.D.; Worley, L.A.; Tuscan, M.D.; Harbour, J.W. An accurate, clinically feasible multi-gene expression assay for predicting metastasis in uveal melanoma. J. Mol. Diagn. 2010, 12, 461-468. [CrossRef] [PubMed]

16. Onken, M.D.; Worley, L.A.; Ehlers, J.P.; Harbour, J.W. Gene expression profiling in uveal melanoma reveals two molecular classes and predicts metastatic death. Cancer Res. 2004, 64, 7205-7209. [CrossRef] [PubMed]

17. Robertson, A.G.; Shih, J.; Yau, C.; Gibb, E.A.; Oba, J.; Mungall, K.L.; Hess, J.M.; Uzunangelov, V.; Walter, V.; Danilova, L.; et al. Integrative analysis identifies four molecular and clinical subsets in uveal melanoma. Cancer Cell 2017, 32, 204-220.e15. [CrossRef]

18. Cancer Genome Atlas Network. Genomic classification of cutaneous melanoma. Cell 2015, 161, 1681-1696. [CrossRef]

19. Johansson, P.; Aoude, L.G.; Wadt, K.; Glasson, W.J.; Warrier, S.K.; Hewitt, A.W.; Kiilgaard, J.F.; Heegaard, S.; Isaacs, T.; Franchina, M.; et al. Deep sequencing of uveal melanoma identifies a recurrent mutation in PLCB4. Oncotarget 2016, 7, 4624-4631. [CrossRef]

20. Van Raamsdonk, C.D.; Bezrookove, V.; Green, G.; Bauer, J.; Gaugler, L.; O’Brien, J.M.; Simpson, E.M.; Barsh, G.S.; Bastian, B.C. Frequent somatic mutations of GNAQ in uveal melanoma and blue naevi. Nature 2009, 457, 599-602. [CrossRef] 
21. Van Raamsdonk, C.D.; Griewank, K.G.; Crosby, M.B.; Garrido, M.C.; Vemula, S.; Wiesner, T.; Obenauf, A.C.; Wackernagel, W.; Green, G.; Bouvier, N.; et al. Mutations in GNA11 in uveal melanoma. N. Engl. J. Med. 2010, 363, 2191-2199. [CrossRef] [PubMed]

22. Onken, M.D.; Worley, L.A.; Long, M.D.; Duan, S.; Council, M.L.; Bowcock, A.M.; Harbour, J.W. Oncogenic mutations in GNAQ occur early in uveal melanoma. Investig. Opthalmol. Vis. Sci. 2008, 49, 5230-5234. [CrossRef] [PubMed]

23. Moore, A.R.; Ceraudo, E.; Sher, J.J.; Guan, Y.; Shoushtari, A.N.; Chang, M.T.; Zhang, J.Q.; Walczak, E.G.; Kazmi, M.A.; Taylor, B.S.; et al. Recurrent activating mutations of G-protein-coupled receptor CYSLTR2 in uveal melanoma. Nat. Genet. 2016, 48, 675-680. [CrossRef] [PubMed]

24. Vader, M.J.C.; Madigan, M.C.; Versluis, M.; Suleiman, H.M.; Gezgin, G.; Gruis, N.A.; Out-Luiting, J.J.; Bergman, W.; Verdijk, R.M.; Jager, M.J.; et al. GNAQ and GNA11 mutations and downstream YAP activation in choroidal nevi. Br. J. Cancer 2017, 117, 884-887. [CrossRef] [PubMed]

25. Möller, I.; Murali, R.; Müller, H.; Wiesner, T.; Jackett, L.A.; Scholz, S.L.; Cosgarea, I.; van de Nes, J.A.; Sucker, A.; Hillen, U.; et al. Activating cysteinyl leukotriene receptor 2 (CYSLTR2) mutations in blue nevi. Mod. Pathol. 2017, 30, 350-356. [CrossRef] [PubMed]

26. Yu, F.-X.; Luo, J.; Mo, J.-S.; Liu, G.; Kim, Y.C.; Meng, Z.; Zhao, L.; Peyman, G.; Ouyang, H.; Jiang, W.; et al. Mutant Gq/11 promote uveal melanoma tumorigenesis by activating YAP. Cancer Cell 2014, 25, 822-830. [CrossRef] [PubMed]

27. Feng, X.; Degese, M.S.; Iglesias-Bartolome, R.; Vaque, J.P.; Molinolo, A.A.; Rodrigues, M.; Zaidi, M.R.; Ksander, B.R.; Merlino, G.; Sodhi, A.; et al. Hippo-independent activation of YAP by the GNAQ uveal melanoma oncogene through a trio-regulated rho GTPase signaling circuitry. Cancer Cell 2014, 25, 831-845. [CrossRef] [PubMed]

28. Moroishi, T.; Hansen, C.G.; Guan, K.-L. The emerging roles of YAP and TAZ in cancer. Nat. Rev. Cancer 2015, 15, 73-79. [CrossRef] [PubMed]

29. Mouti, M.A.; Dee, C.; Coupland, S.E.; Hurlstone, A.F.L. Minimal contribution of ERK1/2-MAPK signalling towards the maintenance of oncogenic GNAQQ209P-driven uveal melanomas in zebrafish. Oncotarget 2016, 7, 39654-39670. [CrossRef]

30. Perez, D.E.; Henle, A.M.; Amsterdam, A.; Hagen, H.R.; Lees, J.A. Uveal melanoma driver mutations in GNAQ/11 yield numerous changes in melanocyte biology. Pigment. Cell Melanoma Res. 2018, 31, $604-613$. [CrossRef]

31. Shain, A.H.; Bagger, M.M.; Yu, R.; Chang, D.; Liu, S.; Vemula, S.; Weier, J.F.; Wadt, K.; Heegaard, S.; Bastian, B.C.; et al. The genetic evolution of metastatic uveal melanoma. Nat. Genet. 2019, 9, 239. [CrossRef] [PubMed]

32. Harbour, J.W.; Onken, M.D.; Roberson, E.D.O.; Duan, S.; Cao, L.; Worley, L.A.; Council, M.L.; Matatall, K.A.; Helms, C.; Bowcock, A.M. Frequent mutation of BAP1 in metastasizing uveal melanomas. Science 2010, 330, 1410-1413. [CrossRef] [PubMed]

33. Field, M.G.; Durante, M.A.; Anbunathan, H.; Cai, L.Z.; Decatur, C.L.; Bowcock, A.M.; Kurtenbach, S.; Harbour, J.W. Punctuated evolution of canonical genomic aberrations in uveal melanoma. Nat. Commun. 2018, 9, 116. [CrossRef] [PubMed]

34. Jensen, D.E.; Proctor, M.; Marquis, S.T.; Gardner, H.P.; Ha, S.I.; Chodosh, L.A.; Ishov, A.M.; Tommerup, N.; Vissing, H.; Sekido, Y.; et al. BAP1: A novel ubiquitin hydrolase which binds to the BRCA1 RING finger and enhances BRCA1-mediated cell growth suppression. Oncogene 1998, 16, 1097-1112. [CrossRef] [PubMed]

35. Zarrizi, R.; Menard, J.A.; Belting, M.; Massoumi, R. Deubiquitination of $\gamma$-tubulin by BAP1 prevents chromosome instability in breast cancer cells. Cancer Res. 2014, 74, 6499-6508. [CrossRef] [PubMed]

36. Peng, J.; Ma, J.; Li, W.; Mo, R.; Zhang, P.; Gao, K.; Jin, X.; Xiao, J.; Wang, C.; Fan, J. Stabilization of MCRS1 by BAP1 prevents chromosome instability in renal cell carcinoma. Cancer Lett. 2015, 369, 167-174. [CrossRef]

37. Ismail, I.H.; Davidson, R.; Gagné, J.-P.; Xu, Z.Z.; Poirier, G.G.; Hendzel, M.J. Germline mutations in BAP1 impair its function in DNA double-strand break repair. Cancer Res. 2014, 74, 4282-4294. [CrossRef]

38. Yu, H.; Pak, H.; Hammond-Martel, I.; Ghram, M.; Rodrigue, A.; Daou, S.; Barbour, H.; Corbeil, L.; Hébert, J.; Drobetsky, E.; et al. Tumor suppressor and deubiquitinase BAP1 promotes DNA double-strand break repair. Proc. Natl. Acad. Sci. USA. 2014, 111, 285-290. [CrossRef]

39. Cerami, E.; Gao, J.; Dogrusoz, U.; Gross, B.E.; Sumer, S.O.; Aksoy, B.A.; Jacobsen, A.; Byrne, C.J.; Heuer, M.L.; Larsson, E.; et al. The cBio cancer genomics portal: An open platform for exploring multidimensional cancer genomics data. Cancer Discovery 2012, 2, 401-404. [CrossRef] 
40. Gao, J.; Aksoy, B.A.; Dogrusoz, U.; Dresdner, G.; Gross, B.; Sumer, S.O.; Sun, Y.; Jacobsen, A.; Sinha, R.; Larsson, E.; et al. Integrative analysis of complex cancer genomics and clinical profiles using the cBioPortal. Sci Signal 2013, 6, pl1. [CrossRef]

41. Bakhoum, S.F.; Cantley, L.C. The multifaceted role of chromosomal instability in cancer and its microenvironment. Cell 2018, 174, 1347-1360. [CrossRef] [PubMed]

42. Bakhoum, S.F.; Ngo, B.; Laughney, A.M.; Cavallo, J.-A.; Murphy, C.J.; Ly, P.; Shah, P.; Sriram, R.K.; Watkins, T.B.K.; Taunk, N.K.; et al. Chromosomal instability drives metastasis through a cytosolic DNA response. Nature 2018, 553, 467-472. [CrossRef] [PubMed]

43. Bakhoum, S.F.; Compton, D.A. Chromosomal instability and cancer: A complex relationship with therapeutic potential. J. Clin. Invest. 2012, 122, 1138-1143. [CrossRef] [PubMed]

44. Lengauer, C.; Kinzler, K.W.; Vogelstein, B. Genetic instabilities in human cancers. Nature 1998, 396, 643-649. [CrossRef] [PubMed]

45. Thompson, S.L.; Compton, D.A. Examining the link between chromosomal instability and aneuploidy in human cells. J. Cell Biol. 2008, 180, 665-672. [CrossRef]

46. Laughney, A.M.; Elizalde, S.; Genovese, G.; Bakhoum, S.F. Dynamics of tumor heterogeneity derived from clonal karyotypic evolution. Cell Rep. 2015, 12, 809-820. [CrossRef] [PubMed]

47. Damato, B.; Duke, C.; Coupland, S.E.; Hiscott, P.; Smith, P.A.; Campbell, I.; Douglas, A.; Howard, P. Cytogenetics of uveal melanoma: A 7-year clinical experience. Ophthalmology 2007, 114, 1925-1931. [CrossRef]

48. Shields, C.L.; Ganguly, A.; Bianciotto, C.G.; Turaka, K.; Tavallali, A.; Shields, J.A. Prognosis of uveal melanoma in 500 cases using genetic testing of fine-needle aspiration biopsy specimens. Ophthalmology 2011, 118, $396-401$. [CrossRef]

49. Shields, C.L.; Kaliki, S.; Furuta, M.; Fulco, E.; Alarcon, C.; Shields, J.A. American joint committee on cancer classification of uveal melanoma (anatomic stage) predicts prognosis in 7,731 patients: The 2013 zimmerman lecture. Ophthalmology 2015, 122, 1180-1186. [CrossRef]

50. White, V.A.; Chambers, J.D.; Courtright, P.D.; Chang, W.Y.; Horsman, D.E. Correlation of cytogenetic abnormalities with the outcome of patients with uveal melanoma. Cancer 1998, 83, 354-359. [CrossRef]

51. Van Engen-van Grunsven, A.C.H.; Baar, M.P.; Pfundt, R.; Rijntjes, J.; Küsters-Vandevelde, H.V.N.; Delbecq, A.-L.; Keunen, J.E.; Klevering, J.B.; Wesseling, P.; Blokx, W.A.M.; et al. Whole-genome copy-number analysis identifies new leads for chromosomal aberrations involved in the oncogenesis and metastastic behavior of uveal melanomas. Melanoma Res. 2015, 25, 200-209. [CrossRef]

52. Royer-Bertrand, B.; Torsello, M.; Rimoldi, D.; El Zaoui, I.; Cisarova, K.; Pescini-Gobert, R.; Raynaud, F.; Zografos, L.; Schalenbourg, A.; Speiser, D.; et al. Comprehensive genetic landscape of uveal melanoma by whole-genome sequencing. Am. J. Hum. Genet. 2016, 99, 1190-1198. [CrossRef] [PubMed]

53. Turner, K.M.; Deshpande, V.; Beyter, D.; Koga, T.; Rusert, J.; Lee, C.; Li, B.; Arden, K.; Ren, B.; Nathanson, D.A.; et al. Extrachromosomal oncogene amplification drives tumour evolution and genetic heterogeneity. Nature 2017, 543, 122-125. [CrossRef] [PubMed]

54. Klutstein, M.; Nejman, D.; Greenfield, R.; Cedar, H. DNA methylation in cancer and aging. Cancer Res. 2016, 76, 3446-3450. [CrossRef] [PubMed]

55. Zou, Y.; Li, J.; Chen, Y.; Xiao, H.; Zhang, F.; Yu, D.; Luo, K. BANCR: A novel oncogenic long non-coding RNA in human cancers. Oncotarget 2017, 8, 94997-95004. [CrossRef]

56. Yu, Y.; Yang, J.; Li, Q.; Xu, B.; Lian, Y.; Miao, L. LINC00152: A pivotal oncogenic long non-coding RNA in human cancers. Cell Prolif. 2017, 50, e12349. [CrossRef] [PubMed]

57. Colombo, T.; Farina, L.; Macino, G.; Paci, P. PVT1: A rising star among oncogenic long noncoding RNAs. Biomed. Res. Int. 2015, 2015, 304208. [CrossRef]

58. Maat, W.; Ly, L.V.; Jordanova, E.S.; de Wolff-Rouendaal, D.; Schalij-Delfos, N.E.; Jager, M.J. Monosomy of chromosome 3 and an inflammatory phenotype occur together in uveal melanoma. Invest. Ophthalmol. Vis. Sci. 2008, 49, 505-510. [CrossRef]

59. Bronkhorst, I.H.G.; Vu, T.H.K.; Jordanova, E.S.; Luyten, G.P.M.; Burg, S.H.V.D.; Jager, M.J. Different subsets of tumor-infiltrating lymphocytes correlate with macrophage influx and monosomy 3 in uveal melanoma. Investig. Opthalmol. Vis. Sci. 2012, 53, 5370-5378. [CrossRef]

60. La Cruz de, P.O.; Specht, C.S.; McLean, I.W. Lymphocytic infiltration in uveal malignant melanoma. Cancer 1990, 65, 112-115. [CrossRef] 
61. Whelchel, J.C.; Farah, S.E.; McLean, I.W.; Burnier, M.N. Immunohistochemistry of infiltrating lymphocytes in uveal malignant melanoma. Invest. Ophthalmol. Vis. Sci. 1993, 34, 2603-2606. [PubMed]

62. Gezgin, G.; Dogrusöz, M.; van Essen, T.H.; Kroes, W.G.M.; Luyten, G.P.M.; van der Velden, P.A.; Walter, V.; Verdijk, R.M.; van Hall, T.; van der Burg, S.H.; et al. Genetic evolution of uveal melanoma guides the development of an inflammatory microenvironment. Cancer Immunol. Immunother. 2017, 66, 903-912. [CrossRef] [PubMed]

63. Mäkitie, T.; Summanen, P.; Tarkkanen, A.; Kivelä, T. Tumor-infiltrating macrophages (CD68(+) cells) and prognosis in malignant uveal melanoma. Invest. Ophthalmol. Vis. Sci. 2001, 42, 1414-1421. [PubMed]

64. Pencik, J.; Pham, H.T.T.; Schmoellerl, J.; Javaheri, T.; Schlederer, M.; Culig, Z.; Merkel, O.; Moriggl, R.; Grebien, F.; Kenner, L. JAK-STAT signaling in cancer: From cytokines to non-coding genome. Cytokine 2016, 87, 26-36. [CrossRef] [PubMed]

65. Bousoik, E.; Montazeri Aliabadi, H. “Do we know jack” about JAK? A closer look at JAK/STAT signaling pathway. Front. Oncol. 2018, 8, 287. [CrossRef] [PubMed]

66. Jager, M.J.; Brouwer, N.J.; Esmaeli, B. The cancer genome atlas project: An integrated molecular view of uveal melanoma. Ophthalmology 2018, 125, 1139-1142. [CrossRef] [PubMed]

67. Vichitvejpaisal, P.; Dalvin, L.A.; Mazloumi, M.; Ewens, K.G.; Ganguly, A.; Shields, C.L. Genetic analysis of uveal melanoma in 658 patients using the cancer genome atlas classification of uveal melanoma as A., B., C., and D. Ophthalmology 2019. [CrossRef] [PubMed]

68. Klufas, M.A.; Itty, S.; McCannel, C.A.; Glasgow, B.J.; Moreno, C.; McCannel, T.A. Variable results for uveal melanoma-specific gene expression profile prognostic test in choroidal metastasis. JAMA Ophthalmol. 2015, 133, 1073-1076. [CrossRef] [PubMed]

69. Chen, X.; Wu, Q.; Tan, L.; Porter, D.; Jager, M.J.; Emery, C.; Bastian, B.C. Combined PKC and MEK inhibition in uveal melanoma with GNAQ and GNA11 mutations. Oncogene 2014, 33, 4724-4734. [CrossRef]

70. Chattopadhyay, C.; Kim, D.W.; Gombos, D.S.; Oba, J.; Qin, Y.; Williams, M.D.; Esmaeli, B.; Grimm, E.A.; Wargo, J.A.; Woodman, S.E.; et al. Uveal melanoma: From diagnosis to treatment and the science in between. Cancer 2016, 122, 2299-2312. [CrossRef]

71. Lapadula, D.; Farias, E.; Randolph, C.E.; Purwin, T.J.; McGrath, D.; Charpentier, T.H.; Zhang, L.; Wu, S.; Terai, M.; Sato, T.; et al. Effects of oncogenic G $\alpha$ q and G $\alpha 11$ inhibition by FR900359 in uveal melanoma. Mol. Cancer Res. 2019, 17, 963-973. [CrossRef] [PubMed]

72. Takasaki, J.; Saito, T.; Taniguchi, M.; Kawasaki, T.; Moritani, Y.; Hayashi, K.; Kobori, M. A novel Galphaq/11-selective inhibitor. J. Biol. Chem. 2004, 279, 47438-47445. [CrossRef] [PubMed]

73. Schrage, R.; Schmitz, A.-L.; Gaffal, E.; Annala, S.; Kehraus, S.; Wenzel, D.; Büllesbach, K.M.; Bald, T.; Inoue, A.; Shinjo, Y.; et al. The experimental power of FR900359 to study Gq-regulated biological processes. Nat. Commun. 2015, 6, 10156. [CrossRef] [PubMed]

74. Xiong, X.-F.; Zhang, H.; Underwood, C.R.; Harpsøe, K.; Gardella, T.J.; Wöldike, M.F.; Mannstadt, M.; Gloriam, D.E.; Bräuner-Osborne, H.; Strømgaard, K. Total synthesis and structure-activity relationship studies of a series of selective G protein inhibitors. Nat. Chem. 2016, 8, 1035-1041. [CrossRef] [PubMed]

75. Annala, S.; Feng, X.; Shridhar, N.; Eryilmaz, F.; Patt, J.; Yang, J.; Pfeil, E.M.; Cervantes-Villagrana, R.D.; Inoue, A.; Häberlein, F.; et al. Direct targeting of $\mathrm{G} \alpha \mathrm{q}$ and $\mathrm{G} \alpha 11$ oncoproteins in cancer cells. Sci. Signal. 2019, 12, eaau5948. [CrossRef] [PubMed]

76. Onken, M.D.; Makepeace, C.M.; Kaltenbronn, K.M.; Kanai, S.M.; Todd, T.D.; Wang, S.; Broekelmann, T.J.; Rao, P.K.; Cooper, J.A.; Blumer, K.J. Targeting nucleotide exchange to inhibit constitutively active G protein $\alpha$ subunits in cancer cells. Sci. Signal. 2018, 11, eaao6852. [CrossRef]

77. Sagiv, O.; Thakar, S.D.; Kandl, T.J.; Ford, J.; Sniegowski, M.C.; Hwu, W.-J.; Esmaeli, B. Immunotherapy with programmed cell death 1 inhibitors for 5 patients with conjunctival melanoma. JAMA Ophthalmol. 2018, 136, 1236-1241. [CrossRef]

78. Samstein, R.M.; Lee, C.-H.; Shoushtari, A.N.; Hellmann, M.D.; Shen, R.; Janjigian, Y.Y.; Barron, D.A.; Zehir, A.; Jordan, E.J.; Omuro, A.; et al. Tumor mutational load predicts survival after immunotherapy across multiple cancer types. Nat. Genet. 2019, 51, 202-206. [CrossRef]

(C) 2019 by the authors. Licensee MDPI, Basel, Switzerland. This article is an open access article distributed under the terms and conditions of the Creative Commons Attribution (CC BY) license (http://creativecommons.org/licenses/by/4.0/). 